STUDIA PRAWNO-EKONOMICZNE, T. CXIV, 2020

PL ISSN 0081-6841; e-ISSN 2450-8179 $\quad$ s. 295-312

https://doi.org/10.26485/SPE/2020/114/16

Takashi MASUYAMA*

iD https://orcid.org/0000-0002-6899-8976

\title{
A STUDY ON THE INEFFECTIVENESS OF JAPAN'S STEWARDSHIP CODE (2014) CONFRONTED WITH JAPAN'S FAIR DISCLOSURE RULE (2018)
}

\begin{abstract}
Background: Abenomics is a policy mix that was designed and introduced by the Liberal Democratic Party (LDP) in Japan. It aims to revive the Japanese economy and has been advocated by Prime Minister Shinzo Abe and his Cabinet since December 2012. Since 1989, Japan has experienced a severe financial crisis and almost 30 years of economic stagnation, known as the "Lost Decades".

Research purpose: This study examines the ineffectiveness of one of Abenomics' solutions, Japan's Stewardship Code (2014), "the Code," confronted with Japan's Fair Disclosure Rule (2018). The Code aims to both enhance returns for financial investors and foster the corporate value and sustainable growth of investee companies. The purpose of this study is, first, to clarify the relationship between stock prices and earnings-to-price ratios in the Japanese stock market, reflecting the worst performance period of 1989-2018, when stock prices continuously declined. The second is to judge whether it is meaningful or meaningless to carry out the Code from a long-term investors' perspective. Methods: I used an approach by Brealey, Myers, and Allen (2008), where a discount dividend model and the net present value of future-growth opportunities are discussed.
\end{abstract}

Conclusions: I concluded that it would surely be ineffective to carry out the Code in Japan.

Keywords: Abenomics, conflicts of interests, corporate governance.

JEL classification: N25

\section{Introduction}

\subsection{Rationale behind the study}

Abenomics is a policy mix that was designed and introduced by the Liberal Democratic Party (LDP) in Japan. It aims to revive the Japanese economy and has been advocated by Prime Minister Shinzo Abe and his Cabinet since December 2012. According to the LDP's "Japan Revitalization Strategy", which

* Professor, Faculty of Economics, Josai University, Japan; e-mail: lobolobo@josai.ac.jp 
was revised in June 2014, one of the three key policy measures ${ }^{1}$ to restore Japanese firms' earning power is to enhance corporate governance. Japan's Nikkei stock average hit an all-time high in 1989, only to crash in a spectacular manner shortly after, causing the Japanese real estate bubble to collapse and throwing the country into a severe financial crisis and a long, nearly 30-year period of economic stagnation, known as the "Lost Decades".

Japan's Stewardship Code, 2014 (the Code, hereafter) is an unfamiliar concept to the Japanese. Nevertheless, it is one of the solutions that is expected to strengthen both corporate earnings and corporate governance. Other solutions include the revision of Japan's Companies Act, which imposes accountability on firms with no outside directors, and the restructuring of the Government Pension Investment Fund (GPIF) ${ }^{2}$. Each solution should not be evaluated as an independent policy, but rather judged as an element of the policy-mix effects, if such effects exist, in line with an economic theory.

From an academic perspective, there are several controversial points regarding the Code that should be discussed in relation to the revitalization of firms' earnings. My research question is whether the Code is theoretically meaningful in terms of increasing earnings per share (EPS) under the Japanese longterm downtrend of stock prices.

\subsection{What are Stewardship responsibilities?}

By definition", the Code states that "stewardship responsibilities" refers to the responsibilities of institutional investors to enhance the medium to long-term investment return of their clients and beneficiaries, including ultimate benefi-

1 Prime Minister Shinzo Abe and his Cabinet decided the original strategy on 14 June 2013. The 2014 revised three key measures of the "1. Restoring Japan's Earning Power (1) Companies to Change" are (1)enhancing corporate governance, (2) Reforming investment of public and quasi-public funds and (3)Accelerating industrial restructuring and venture businesses, promoting provision of funds for growth.

2 Bloomberg reported on Feb 17, 2014 that GPIF was the largest pension fund in the world, with 124 trillion Japanese yen. The Japanese equity investment portfolio portion is now $24 \%$ and is expected to increase. The Gordon growth model (dividend discount model) is a method of valuing a firm's stock on the ground that its stock is worth the sum of all dividends, and is named after Myron J. Gordon.

3 Financial Service Agency, Principles for Responsible Institutional Investors - Japan's - Stewardship Code - To promote sustainable growth of companies through investment and dialogue, The Council of Experts Concerning the Japanese version of Stewardship Code, 2014, p. 1. Also, a bill regulating securities companies and investee companies, which requires the prompt and fair disclosure of important corporate information to the public was passed and 
ciaries. They should do so by improving and fostering the investee companies' corporate value and sustainable growth, through constructive engagement or purposeful dialogue, based on in-depth knowledge of the companies and their business environment.

\subsection{Purpose of the study}

Here, two kinds of conflicts of interest seem to exist. The first one is located between (1) "enhancing return for clients" and (2) "improving and fostering the investee companies' corporate value". Economically, (1) and (2) are completely different and opposite; nevertheless, the Code aims at a "win-win" relationship. As a result, enhancing investee companies' corporate earnings by utilizing investors' power may not work. Looking back over the overall negative stock market performances of the past 29 years, institutional investors have suffered and will still face difficulties in raising both their own returns and firms' return on equity (ROE). In addition, investors are obliged to take for granted a huge market risk over a longer investment period and may lose money in the end. The second conflict of interest is the so-called "principal-agency"4 problem where investors - agencies face information asymmetry, where less-informed investors conduct both (3) constructive engagement, for instance, to acquire in-depth knowledge of the investee companies, and (4) long-term investment in the same companies under the Code.

In the long-term, when overall stock prices are declining, does this Code really compensate for the capital losses and the costs associated with these engagements? And hence, is it worth investing in Japan?

This paper only deals with the first conflict of interest between (1) and (2).

The purpose of this study is, first, to clarify the relationship between stock prices and EPS in the Japanese stock market from 1989 to 2018, i.e., the period of the market's worst performance, when stock prices were declining. The second is to judge whether conducting the Code is meaningful or meaningless from a long-term investors' perspective.

finally enacted on April 1, 2018, as Japan's Fair Disclosure Rule (2018), by the Japanese Government.

4 E. Fama (Agency Problems and the Theory of the Firm in the Journal of Political Economy, 88 (2), The University of Chicago Press, 1980, pp. 288-307), for example, attempts to explain how the separation of security ownership and control, typically in large corporations, can be an efficient form of economic organization. 


\section{A retrospective of previous studies}

\subsection{History of Stewardship}

According to the Oxford Learner's Dictionary ${ }^{5}$, stewardship is defined as the act of taking care of or managing something, for example, property, an organization, money, or valuable objects. The American Heritage Dictionary states that stewardship was a term used to describe a social or domestic relationship between the landlord (owner) and the guardian (keeper), where fiduciary duty was established. In addition, in Medieval England, the terms "use", "charity", and "trust" were embodied examples of the fiduciary duties of reserving and protecting the landlord's assets against a third party. Even earlier, estate and inheritance law existed in the Roman Era, and they go further back to the $17^{\text {th }}$ and $18^{\text {th }}$ centuries $\mathrm{BC}$, when the establishment of the laws of Hammurabi and Eshnunna is said to have marked the beginning of fiduciary duties.

Recently in Europe, to prevent fraudulent conduct by firms' directors, the possibility of institutional investors' active involvement in investees' board activities has been actively discussed. The UK has a more than 20 -year history of statutory corporate governance design. For instance, the Cadbury Report ${ }^{6}$ introduced the "comply or explain" approach to institutional investors; the Hampel Report ${ }^{8}$ recommended a relational framework for the roles of directors, investors, and auditors. After the collapse of Lehman Brothers in 2008, and the subsequent financial crisis, the Walker Review ${ }^{9}$ established the notion of engaging institutional investors to monitor board remuneration and firms' risk-taking activities, especially in the UK banking industry. In 2010, the first draft of the UK Stewardship Code was completed, in line with the revised UK Corporate

5 The origin of the word steward is the old English "stīweard", a verb dating from the early $17^{\text {th }}$ century, according to Lexico.com, the online dictionary from Oxford University Press.

6 Cadbury Report, Financial Aspects of Corporate Governance, The Committee on the Financial Aspects of Corporate Governance, Gee Publishing Ltd., 1992, pp. 1-64.

7 In the Cadbury Report, in the section on the Statement of Compliance, clause 3.7, the so-called "Comply or explain" is explained as follows: "We recommend that listed companies reporting in respect of years ending after 30 June 1993 should state in the report and accounts whether they comply with the Code and identify and give reasons for any areas of non-compliance. The London Stock Exchange intends to require such a statement as one of its continuing listing obligations".

8 Hampel Report, Committee of Corporate Governance: Final Report, The Committee of Corporate Governance, Gee Publishing Ltd., 1998, pp. 1-60.

9 Walker review, A review of corporate governance in UK banks and other financial industry entities, Final Recommendations, The Walker review secretariat, 2009. 
Governance Code enacted by the Financial Reporting Council ${ }^{10}$. In 2012, the UK Stewardship Code was also revised in line with the Kay Review ${ }^{11}$. In Japan, there are few records of activists' discussions ${ }^{12}$ that present evidence of whether the Code will have positive impacts on corporate earnings, EPS, or an increase in particular stock prices. Academic researchers, as well as business practitioners, have not reached any conclusion or consensus on the controversial issue of how institutional investors affect corporate financial strategy, earnings, and payout policy.

Nevertheless, Japan imitated the UK Stewardship Code and introduced it in 2014. This is perhaps due to the pressure that resulted from the AIJ investment firm fraud ${ }^{13}$ that occurred in 2012, in addition to outside pressures that came from Europe. An OECD report ${ }^{14}$ severely criticized the inefficient system of the GPIF. Its report argued that there was low profitability and short-termism. All these things accelerated the introduction of Japan's Code by Japan's Financial Services Agency (J-FSA) in February 2014. Unlike a law that is an enforceable governmental norm, the "Code" is a voluntary standard or principle, where the self-accountability rule was introduced, and no penalty clause has been attached to non-participation.

\subsection{The Code is now facing difficulties regarding the Fair Disclosure Rule (2018)}

The Fair Disclosure Rule (2018) in Japan naturally restricts selective disclosure by investees. Therefore, institutional investors are now confronted with difficulties in holding aggressive constructive engagements or purposeful dialogue opportunities with those investees. In-depth knowledge of the investee compa-

10 The Financial Reporting Council (FRC) is the UK's independent regulator for the accounting, actuarial professions and is responsible for corporate governance.

11 J. Kay, The Kay Review of UK Equity Markets and Long-term Decision Making Final Report in Department for Business, Innovation and Skills, House of Commons, 2012.

12 Discussion examples are the minutes of the $1^{\text {st }}$ to $6^{\text {th }}$ Councils of Experts concerning the Code. The Council received comments in Japanese from 26 individuals/entities and 19 in English on the draft of the Code. Based on the comments, the Council revised and finalized the Code on February 26, 2014. The final version is provided in the attached Table 1.

13 BBC online news reported on June 19, 2012 that the president of AIJ Investment Advisors and three others had been arrested for fraud relating to 109 billion yen of missing pension funds. Japanese prosecutors said 7 billion yen of the missing money was stolen from clients. More than 880,000 policy holders were affected by the losses.

14 OECD, Options to improve the Governance and Investment of Japan's Government Pension Fund, in Working Papers on Finance, Insurance and private pensions, 2010. 
nies affecting stock prices is more likely to be revealed to relatively large institutional investors through selective disclosure. To make things worse, selective disclosure tends to be an act of revealing insider information. Thus, the Code has suffered a major setback since the Fair Disclosure Rule (2018) was enacted in Japan on April 1, 2018, by the same current Japanese government.

\section{Base of analysis}

\subsection{Data}

The following sets of data were used.

1) Stock Index - Japanese TOPIX (Beg. 1989 - End. 2018); the simple arithmetic average annual yield = minus 1.7\%; Tokyo Stock Exchange data.

2) Japanese Government Bond (JGB): (1989-2018) Duration 29 years; a simple arithmetic annual average yield $=1.1 \%$; Ministry of Finance data, as of June 5, 2019).

3) Other Stock Indices; the American Nasdaq \& Dow Jones Industrials, the German DAX, and the Global Morgan Stanley Capital Index (MSCI).

\subsection{Previous studies and assumptions}

\subsubsection{Modigliani and Miller $(1958,1963)$, the so-called MM proposition I and II}

Modigliani and Miller hypothesized that in proposition I, based on the condition of no transaction or agency costs, in an efficient market with free short selling, etc., the value of a firm is unaffected and irrelevant to how that firm is financed, either by debt or equity. This is the so-called MM proposition I. Further, in proposition II, they argue that the value of a firm stays the same regardless of the dividend payout policy.

\subsubsection{Jensen (1986)}

Jensen argues that, with active monitoring, firms become more likely to pay out their free cash flow, but this does not necessarily mean that payout dividends always increase, because conflicts of interest occur between shareholders and corporate managers. Free cash flow is cash flow in excess of that required to fund all projects that have a positive net present value (NPV). Corporate managers are the agents of shareholders, a relationship fraught with conflicting interests. 


\subsubsection{Fama and French's study (1992)}

Fama and French chose 12 different types of portfolios, each of which consists of values of US stocks ranging from about US\$2 billion to US\$8 billion, for the period 1963-1990. Their aim was to examine whether there was any relationship between the stock return $(r)$ and the earnings-to-price ratio $(E P S / \mathrm{P})$. They discovered that, on average, the larger the $E P S / P$, the larger $r$ becomes.

\subsubsection{Key assumptions of modern portfolio theory ${ }^{15}$}

In a long-term recessionary period, where overall EPS are either very low or negative, and where the earnings-to-price ratio hardly increases, investors are risk averse.

Naturally, under these conditions, from the long-term perspective, investors will wish to sell portfolio stocks. However, for the last two years (i.e., 2012 to 2018), the Japanese stock market index rebounded (TOPIX, year-end), assuming that Japan's overall stock prices are still on a longer-term (29-year) downtrend. In the next model, I denote the price of a typical stock, $P$, and the rate of return on that stock is denoted by $r$.

FIGURE 1: The Structure of Stewardship Responsibilities

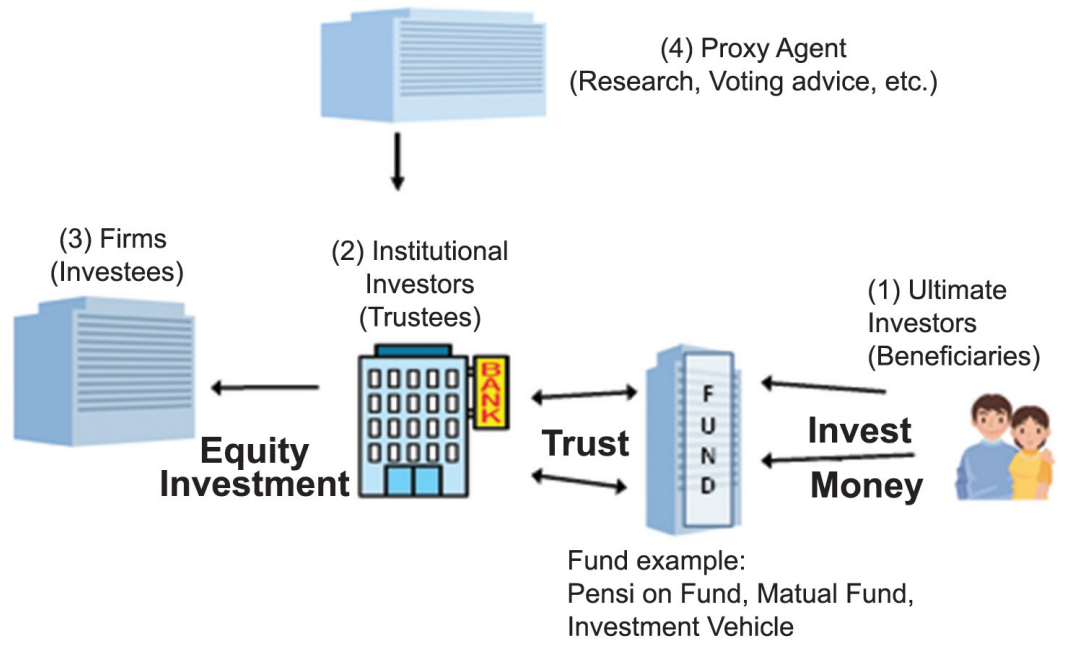

S o u r c e: Author's own compilation.

15 The modern portfolio theory (MPT), a finance theory said to start by Harry Markowitz in his paper Portfolio Selection, Journal of Finance, 1952, on how a risk-averse investor can construct a securities portfolio to maximize an expected rate of return given a certain level of risk is set. 
The Japanese TOPIX chart will clearly indicate its downtrend compared with the major relevant indices of the US and the UK (see Chart 1 in the appendix).

Finally, stewardship in this thesis is limited to the tri-party relationships among ultimate investors (beneficiaries), institutional investors (trustees, trusted by beneficiaries), and firms (investees). Yet, other various types of stewardship exist, for example, four-party-relationships among (1) beneficiaries, (2) trustees, (3) investees, and (4) trustees' proxy agents (see Figure 1).

\section{Analysis}

\subsection{Method - The relationship between stock price and EPS}

This paper adopts the approach of the NPV of future growth opportunities (NPV of G), written by Brealey, Myer, and Allen (BMA, thereafter) as follows:

Investors often denote the terms growth stocks and income (or value) stocks. Investors buy growth stocks mainly for their capital-gain expectations when they hope for future growth of earnings, rather than dividends. In contrast, investors buy income stocks mainly for their cash dividends when they expect low or negative future growth of earnings. $N P V$ of $G$ is useful in determining the net intrinsic value of a new project or an acquisition of another firm. It is calculated by taking the net cash inflow, for example, discounted at the firm's cost of capital, less the present value of a new business or a purchased venture firm.

\subsection{Analysis}

To cover all possibilities, this paper categorized Japanese firms into three different types of cases: (1) the case of the no-growth firm, (2) the case of the growthfirm, and (3) the case of the negative-growth firm.

(Case 1) The case of the no-growth firm, where the $N P V$ of growth opportunities $(N P V$ of $G)=0$

\section{Background Information}

Fama and French ${ }^{16}$ examined the role of the earnings-to-price ratio in returns in the USA on a long-term horizon from 1963 to 1990. They found a tendency for a larger r, given a larger EPS/P. Unlike the USA, Japan's stock prices for the period 1989-2018 were, on an average, on a downtrend of about minus $1.7 \%$ annually.

\footnotetext{
E. Fama, K. French, The Cross-Section of Expected Stock Returns in The Journal of Finance
} 1992/47 (2), pp. 427-465. 
In Case 1, Firm $X$ does not grow at all. $X$ does not plow back any earnings and simply produces a constant stream of dividends, where $D_{1}$ is the one-year dividend paid in Year 1. Here, $D_{1}=D_{2}=D_{3}=D_{n}$. In the real world, X may not always pay a dividend higher than $D_{1}$. Therefore, the overall average dividend level in any year will be regarded as the average dividend, $D_{1}$, as long as $\mathrm{X}$ survives for a long period of time, like a perpetual bond. In a long-term recessionary period, say 29 years, the firm does not grow overall, nor is it expected to grow, even in the future, as a market consensus. Nevertheless, investors still expect to receive at least the same amount of dividends as before. Hence, although the firm's stock price has fallen to less than half of the original purchase price, these investors are satisfied with this firm's long-term strategy. For multiple fiscal years, these investors depreciated the stock's book value to the current market price by realizing accounting capital losses annually, and they no longer expect the stock price to recover to the original purchase price.

\section{Solution to the investor's return}

Let $r$ denote an investor's expected rate of return on stock X, Pnogrowth denote the present value of stock $\mathrm{X}$ (= Stock price of $\mathrm{X})$, and EPS denote the earningsto-price ratio.

In this "case of the no-growth firm", I use a dividend discount model.

Pnogrowth $=\frac{D_{1}}{1+r}+\frac{D_{2}}{(1+r)^{2}}+\frac{D_{3}}{(1+r)^{3}}+\ldots \frac{D_{n}}{(1+r)^{n}}$,

Here, $D_{1}=D_{2}=D_{3}=D_{n}$ constant, and $n \rightarrow \infty$ then, $P=\frac{D_{1}}{r}$ will be induced.

Basic Equation: The expected rate of return on stock $\mathrm{X}=$ dividend yield $=$ $E P S / P$

$$
r=\frac{D_{1}}{P}=\frac{E P S}{P}
$$

(One example: When $P=50, D_{1}=E P S=2.5$, then $\mathrm{r}$ is calculated as 0.05 , which is $5 \%$ )

(Case 2.1) The case of the growth firm

In this case, Pgrowth, the stock price of Xgrowth, is a value of the nogrowth stock $\mathrm{X}$ plus the $N P V$ of the growth opportunities, ( $N P V$ of $G$ ). 
follows:

Pgrowth $=\frac{E P S}{r}+(N P V$ of $G)$, then the earnings-to-price ratio will be as

$$
\frac{E P S}{P}=r\left(1-\frac{N P V \text { of } G}{P}\right) \text { Here, } N P V \text { of } G<P \text { Equation (1) }
$$

To solve for the relationship between $P$ and $E P S$, I prepare two more cases below by utilizing equation (1), for a better understanding.

(Case 2.2) Case of the growth firm where ( $N P G$ of $G)>0, r=$ constant

In stewardship code activities, investors hold dialogues about the future growth of the firm with the firm's directors, and they possibly request that the board raise the (NPV of $G)$.

If the (NPV of $G)$ increases $\uparrow$ and if it gets closer to the value of $P$,

then the value of $\left(1-\frac{N P V \text { of } G}{P}\right)$ decreases $\downarrow$.

As " $(N P V$ of $G)$ gets closer to the value of $P$ " means that the constant portion of its divided becomes relatively smaller than the $N P V$ of its future growth.

Here, $0<N P V$ of $G<P, \triangle N P V$ of $G=\triangle P$, and the dividend in any year is constant, then, obviously, $0<\Delta \frac{N P V \text { of } G}{P}<1$ and $\frac{N P V \text { of } G}{P}$ increases.

$\triangle$ is a differential coefficient called Delta $(\triangle)$.

For example, if Pnogrowth $=50, P=60, \triangle P=10$,

$N P F$ of $G: 0$ (nogrowth) $\rightarrow 10, \triangle(N P V$ of $G)=10$,

then $\frac{N P V \text { of } G}{P}=10 / 50 \rightarrow 20 / 60$. stant.

As a result, the direction and value of $\frac{E P S}{P}$ also decrease if $r$ stays conWe can find that $\frac{E P S}{P}$ and $(N P V$ of $G)$ go in opposite directions, and are revelsey related related 
Findings:

We find an important fact. As a result of Stewardship code activities: If $\frac{N P V \text { of } G}{P}$ increases, $\frac{E P S}{P}$ decreases, that is, PER increases.

If $P$ constantly decreases for a long time, then the value of $E P S$ decreases at a faster speed than P's decline, by the definition of equation (1).

(Case 2.3) Growth case, where (NPG of $G)>0$ and $\mathrm{r}$ increases:

In (Case 2.2), some people may argue that the assumption that $r=$ constant is unlikely. Therefore, let me propose a case where $r$ is not constant, but increasing. Here, an incremental value of $r$ is smaller than that of $\frac{E P S}{P}$ of by equation (1).

$$
r_{t \rightarrow t+1}<\Delta \frac{E P S}{P}
$$

In a recessionary period, where $\frac{E P S}{P}$ hardly increases,

Conclusion:

In a recession, it is much more difficult to increase, $r$, since $\Delta r$ is smaller than $\Delta \frac{E P S}{P}$.

Therefore, in Case 2.3, trying to increase will not happen easily.

Small investors may seek to sell this stock to exit, or fairly large investors simply hold their existing portfolio as it is, without any stewardship activities to increase $\frac{E P S}{P}$.

(Case 3) Case of the negative-growth firm, where $(N P G$ of $G)<0$

Let us consider the Japanese stock market and economic situations in the period 1989-2018 
Consider that ( $N P V$ of $G$ ) decreases $\downarrow$, passes zero, and dips into the negative-value zone

Then, the value of $\left(1-\frac{N P V \text { of } G}{P}\right)$ increases $\uparrow$,

just as we saw in (Case 2).

As a result, the direction of $\frac{E P S}{P}$ also increases $\uparrow$, when the $\mathrm{r}$ level stays the same. The phenomenon means, in other words, that investors want to keep the same rate of return of $r$ as the previous year's. Here, $r$ obviously does not increase.

Conclusion:

$\frac{E P S}{P}$ has to increase, otherwise, investors are unable to keep the same $r$ rate as before, since investors want at least a stable and unchanged rate of $r$.

Therefore, $\frac{E P S}{P}$ has to increase, even in the depression period of 1989-2018 to keep the same rate of return $(r)$.

Consequently, it is natural that investors urge the firm's directors to increase $E P S$, by repurchasing the existing number of shares issued.

As to the EPS itself, it is difficult to increase earnings. As a result, the denominator, $P$, the number of shares, has to decrease in order to increase the EPS. In other words, earnings and number of shares are reversely related to keep the same EPS level.

Now, by way of introducing the Code, the Japanese Government generally tries to discourage firms' management from undertaking a share repurchase activity, since a share repurchase activity reduces both retained earnings and reserves in capital accounts. For a firm, a share repurchase is a zero- $N P V$ project. Suppose that the tradeoff is between running the risk of a new capital investment by the management and a share repurchase. Obviously, the shareholders would prefer a share repurchase to a negative $N P V$ project. In Japan's long history of negative $N P V$ of growth opportunities, Japanese firms were reluctant to accept negative- $N P V$ projects. 
Let us imagine a macro world:

$$
f(x)=\text { Corporate Sector of } G N P=\alpha+\beta \sum_{n=1}^{n}\left(\text { Ernings }_{n}\right)+e
$$

Here, $e$ is $a$ standardized error.

In a deteriorating economy, the corporate section of GNP is decreasing, which means that earnings in each firm are, on average, becoming lower since the aggregate of earnings becomes low.

Conclusion:

The alternative way of increasing $\frac{E P S}{P}$ is to decrease $P$, on the condition that the relative decrease of $E P S$ is smaller than the decrease in $P$.

That is, $\triangle$ of $E P S<\triangle$ of $P$

If stock prices inevitably and continuously decline, and if there is no proper way to sell off to exit from the stock market, then such an investor gives up worrying too much about the long-term decline of portfolio stock prices as long as those EPSs are not declining as much. Instead, investors hope portfolio stock prices surpass the competing benchmark index performances, which is also a negative performance.

This is what Japanese institutional investors have actually experienced for a very long period, since 1989, until recently. In other words, a "sell" strategy would have resulted in the best performance ever. However, these investors could not sell to exit because the size of their portfolios was already too enormous to sell out everything.

\section{Concluding remarks}

This paper examined the role of $E P S / P$ in returns. I used $E P S / P$ because the earnings-to-price ratio is a link between the expected return on investment $(r)$ and the fair value of a stock $(P)$. In addition, examining the relationship between $E P S / P$ and $\mathrm{r}$ helps judge whether it is meaningful or not to carry out the Code from a long-term investors' perspective.

If the investment-return $(r)$ component is only a constant dividend, $r$ will be exactly the same as the yearly dividend/price of the stock, as we see in (Case 1). 
I intentionally set up a series of (Case 2.1) through (Case 2.3), because Japan's Stewardship Code is said to enhance corporate earnings by growing and generating new cash in the long run. In other words, $E P S / P$ is a measure of future growth. A notion of the net present value of growth opportunities is to evaluate whether the Code effectively or ineffectively generates cash for the firm through the activities of the investors. Here, in (Case 2.2), an interesting and meaningful result was induced. That is, when $\frac{N P V \text { of } G}{P}$ increases, $\frac{E P S}{P}$ decreases; the $N P V$ of $G$ and $E P S$ are reversely related. In addition, investors will be reluctant to see the findings in (Case 2.3), where $\Delta r_{t \rightarrow t+1}<\Delta \frac{E P S}{P}$. This fact will discourage the Code promoters because the endeavor to increase the investment return $r$ is not paying off, compared with the endeavor to increase $\frac{E P S}{P}$.

Also, I examined the case of a negative-growth firm in (Case 3), where I assumed $\mathrm{r}$ does not increase, but tries to remain at least at the same rate of $r$. This is typically considered to be a value stock investment, where the retirement of the stock occurred due to the activity of the firm's management. In (Case 3), long-term growth in earnings is unlikely. Therefore, Japan will face difficulties in carrying out the Code under a long-term bear stock market.

FIGURE 2: Summary: Link amond rate of return, stock price, and earnings to price ratio

- Case 1 (No growth firm) $E P S / P=r=$ Dividend $/ P$

- Case 2.2 (Growth firm, where $r$ is constant)

$E P S / P$ and $(N P V$ of $G)$ go in opposite directions

- Case 2.3 (Growth firm, where $r$ is increasing)

$$
\Delta r_{t \rightarrow t+1}<\Delta E P S / P
$$

- Case 3 (Negative Growth firm) Retirement of stocks to increase $E P S / P$

S o u r c e: Author's own compilation. 
TABLE 1: Comparison between Japan's Stewardship Code (2014) and the UK Stewardship Code (2012)

\begin{tabular}{|c|c|c|}
\hline Article & Japan's Stewardship Code (2014) & UK Stewardship Code (2012) \\
\hline 1 & 2 & 3 \\
\hline 1 . & $\begin{array}{l}\text { Institutional investors should have } \\
\text { a clear policy on how they fulfill } \\
\text { their stewardship responsibilities, } \\
\text { and publicly disclose this. }\end{array}$ & $\begin{array}{l}\text { Stewardship aims to promote the long-term } \\
\text { success of companies in such a way that the } \\
\text { ultimate providers of capital also prosper. } \\
\text { Effective stewardship benefits companies, } \\
\text { investors, and the economy as a whole. }\end{array}$ \\
\hline 2. & $\begin{array}{l}\text { Institutional investors should have } \\
\text { a clear policy on how they manage } \\
\text { conflicts of interest in fulfilling their } \\
\text { stewardship responsibilities and } \\
\text { publicly disclose this policy. }\end{array}$ & $\begin{array}{l}\text { In publicly listed companies, responsibility for } \\
\text { stewardship is shared. The primary respon- } \\
\text { sibility rests with the board of the company, } \\
\text { which oversees the actions of its management. } \\
\text { Investors in the company also play an import- } \\
\text { ant role in holding the board to account for the } \\
\text { fulfillment of its responsibilities. }\end{array}$ \\
\hline 3. & $\begin{array}{l}\text { Institutional investors should } \\
\text { monitor investee companies so that } \\
\text { they can appropriately fulfill their } \\
\text { stewardship responsibilities with an } \\
\text { orientation towards the sustainable } \\
\text { growth of these companies. }\end{array}$ & $\begin{array}{l}\text { The UK Corporate Governance Code iden- } \\
\text { tifies the principles that underlie an effective } \\
\text { board. The UK Stewardship Code sets out the } \\
\text { principles of effective stewardship by inves- } \\
\text { tors. In so doing, the Code assists institutional } \\
\text { investors to better exercise their stewardship } \\
\text { responsibilities, which in turn gives force to } \\
\text { the "comply or explain" system. }\end{array}$ \\
\hline 4. & $\begin{array}{l}\text { Institutional investors should seek to } \\
\text { arrive at a common understanding } \\
\text { with investee companies and work to } \\
\text { solve problems through constructive } \\
\text { engagement with investee compa- } \\
\text { nies. }\end{array}$ & $\begin{array}{l}\text { For investors, stewardship is more than just } \\
\text { voting. Activities may include monitoring and } \\
\text { engaging with companies on matters, such as } \\
\text { strategy, performance, risk, capital structure, } \\
\text { and corporate governance in areas that include } \\
\text { culture and remuneration. Engagement is } \\
\text { purposeful dialogue with companies on these } \\
\text { matters as well as on issues that are the imme- } \\
\text { diate subject of votes at general meetings. }\end{array}$ \\
\hline 5. & $\begin{array}{l}\text { Institutional investors should have } \\
\text { a clear policy on voting and the dis- } \\
\text { closure of voting activity. The policy } \\
\text { on voting should not be comprised } \\
\text { only of a mechanical checklist; it } \\
\text { should be designed to contribute to } \\
\text { the sustainable growth of investee } \\
\text { companies. }\end{array}$ & $\begin{array}{l}\text { Institutional investors' activities include } \\
\text { decision making on matters such as allocat- } \\
\text { ing assets, awarding investment mandates, } \\
\text { designing investment strategies, and buying or } \\
\text { selling specific securities. The division of du- } \\
\text { ties within and between institutions may span } \\
\text { a spectrum, such that some may be considered } \\
\text { asset owners and others asset managers. }\end{array}$ \\
\hline
\end{tabular}


TABLE 1 (cont.)

\begin{tabular}{|c|l|l|}
\hline 1 & \multicolumn{1}{|c|}{2} & \multicolumn{1}{|c|}{3} \\
\hline 6. & $\begin{array}{l}\text { In principle, institutional investors } \\
\text { should periodically report on how } \\
\text { they fulfill their stewardship re- } \\
\text { sponsibilities, including their voting } \\
\text { responsibilities, to their clients and } \\
\text { beneficiaries. }\end{array}$ & $\begin{array}{l}\text { Broadly speaking, asset owners include } \\
\text { pension funds, insurance companies, invest- } \\
\text { ment trusts, and other collective investment } \\
\text { vehicles. As the providers of capital, they set } \\
\text { the tone for stewardship and may influence } \\
\text { behavioral changes that lead to better stew- } \\
\text { ardship by asset managers and companies. } \\
\text { Asset managers, with daily responsibility for } \\
\text { managing investments, are well positioned to } \\
\text { influence companies' long-term performance } \\
\text { through stewardship. }\end{array}$ \\
\hline 7. & $\begin{array}{l}\text { To positively contribute to the } \\
\text { sustainable growth of investee } \\
\text { companies, institutional investors } \\
\text { should have in-depth knowledge of } \\
\text { the investee companies and their } \\
\text { business environment, and skills and } \\
\text { resources needed to appropriately } \\
\text { engage with the companies. }\end{array}$ & $\begin{array}{l}\text { Compliance with the Code does not constitute } \\
\text { an invitation to manage the affairs of a com- } \\
\text { pany or preclude a decision to sell a holding, } \\
\text { where this is considered in the best interest of } \\
\text { clients or beneficiaries. }\end{array}$ \\
\hline
\end{tabular}

S o u r e e: The above two original codes both in Japan and UK.

CHART 1. Historical Relative Stock Prices (Year 1989+100)

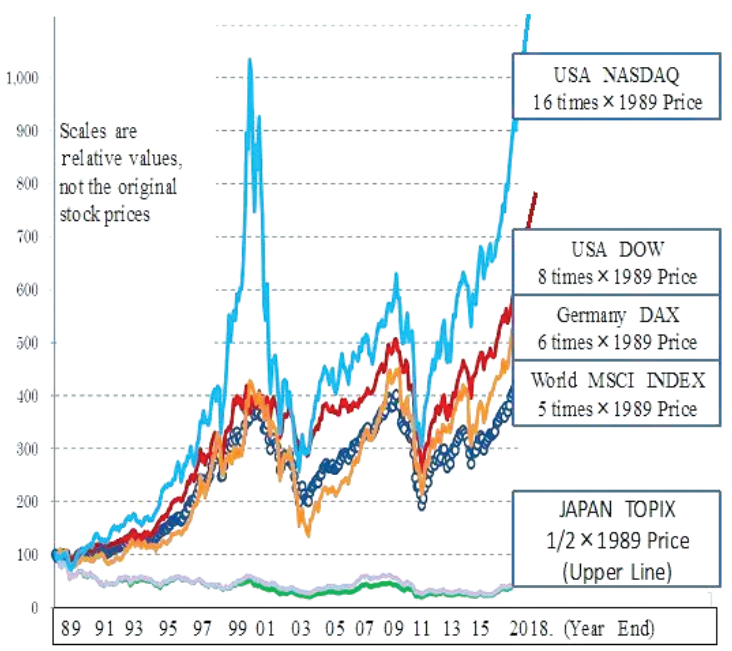

S o u r c e: Author's own compilation on original data by Tokyo Marine \& Nichido Fire Insurance. 


\title{
References
}

Brealey R., Myer S., Allen F. (BMA), Corporate Finance, Eighth Edition, McGraw-Hill International Edition, 2006.

Cadbury Report, Financial Aspects of Corporate Governance, The Committee on the Financial Aspects of Corporate Governance, Gee Publishing Ltd., 1992, pp. 1-64.

Fama E., Agency Problems and the Theory of the Firm in Journal of Political Economy 1980/1988 (2), The University of Chicago Press, pp. 288-307.

Fama, E., French K., The Cross-Section of Expected Stock Returns in The Journal of Finance 1992/47 (2), pp. 427-465.

Financial Reporting Council, UK, The UK Stewardship Code, Code: Corporate Governance, September 2012.

Financial Service Agency, Japan, Fair Disclosure Rule, Financial Instruments and Exchange Act Japan, Act No.25, Article 27: Sub-36, the Original Act enacted on April 13, 1948, amended on April 1, 2018.

Financial Service Agency, Japan, Principles for Responsible Institutional Investors Japan's Stewardship Code) - To promote sustainable growth of companies through investment and dialogue, in The Council of Experts Concerning the Japanese version of Stewardship Code, 2014, p. 1.

Hampel Report, Committee of Corporate Governance: Final Report, The Committee of Corporate Governance, Gee Publishing Ltd., 1998, pp. 1-60.

Jensen M., Agency Costs of Free Cash Flow, Corporate Finance, and Takeovers in American Economic Review 1986/76 (2), pp. 323-329.

Kay J., The Kay Review of UK Equity Markets and Long-term Decision Making Final Report in Department for Business, Innovation and Skills, House of Commons, 2012.

Modigliani F., Miller M., Corporate income taxes and the cost of capital: a correction in American Economic Review 1963, 53 (3), pp. 433-443.

Modigliani F., Miller M., The Cost of Capital, Corporation Finance and the Theory of Investment in American Economic Review 1958/48 (3), pp. 261-297.

OECD, Options to improve the Governance and Investment of Japan's Government Pension Fund in Working Papers on Finance, Insurance and private pensions, 2010.

Walker review, A review of corporate governance in UK banks and other financial industry entities, Final Recommendations, The Walker review secretariat, 2009.

Takashi MASUYAMA

\section{ANALIZA NIEEFEKTYWNOŚCI JAPOŃSKIEGO KODEKSU DOBRYCH PRAKTYK (2014) W OBLICZU ZASADY UCZCIWEGO UJAWNIANIA (2018)}

\begin{abstract}
Abstrakt
Przedmiot badań: Niniejszy artykuł analizuje efektywność jednego z założeń Abenomiki - Kodeksu dobrych praktyk (2014), w obliczu Zasady uczciwego ujawniania z 2018 r. Kodeks ma na celu zarówno zwiększanie zwrotu dla inwestorów, jak również wspieranie wzrostu wartości firmy oraz wspieranie zrównoważonego rozwoju spółek, w których dokonano inwestycji.
\end{abstract}


Cel badawczy: w tym badaniu sprawdza się nieskuteczność jednego z rozwiązań Abenomics, japońskiego kodeksu zarządzania (2014), „kodeksu”, skonfrontowanego z japońską zasadą uczciwego ujawniania (2018). Kodeks ma na celu zarówno zwiększenie zwrotu z inwestycji dla inwestorów finansowych, jak i wspieranie wartości korporacyjnej oraz trwałego wzrostu firm, w których dokonano inwestycji. Celem tego badania jest, po pierwsze, wyjaśnienie związku między cenami akcji a stosunkami zysku do ceny na japońskim rynku akcji, odzwierciedlającym najgorszy okres wyników w latach 1989-2018, kiedy ceny akcji stale spadały. Drugi polega na ocenie, czy stosowanie Kodeksu z perspektywy inwestorów dhugoterminowych jest sensowne czy bezsensowne.

Metoda badawcza: W artykule zostało zastosowane podejście Brealeya, Myersa i Allena (2008), w którym omówiony jest model zdyskontowanych dywidend oraz wartość bieżąca netto możliwości wzrostu.

Wyniki: Analiza do wniosku, że zastosowanie Kodeksu dobrych praktyk w Japonii było nieskuteczne.

Słowa kluczowe: Abenomika, konflikt interesów, nadzór korporacyjny. 